\title{
Clinical characteristics and surgical management of spinal cord tumors in non-Caucasian Hispanic children
}

\author{
Fernando C. Ponce-de-León ${ }^{1}$, José A. Choreño-Parra², Erika L. Cano-Camacho, \\ Vicente González-Carranza ${ }^{1}$, Samuel Torres-García ${ }^{1}$, and Parménides Guadarrama-Ortíz ${ }^{3 *}$ \\ ${ }^{1}$ Departament of Neurosurgery, Hospital Infantil de México Federico Gómez, Mexico City, Mexico; ${ }^{2}$ Departament of Clinical Research, Centro \\ Especializado en Neurocirugía y Neurociencias México, Mexico City, Mexico; ${ }^{3}$ Departament of Neurosurgery, Centro Especializado en Neurocirugía \\ y Neurociencias México, Mexico City, Mexico
}

\begin{abstract}
Objective: Little literature exists about spinal cord tumors in Hispanic children. Methods: We conducted a retrospective review in 45 Mexican children presenting with spinal cord tumors between 1985 and 2015. Results: We observed a higher incidence of spinal cord tumors in males (62.22\%). The mean age at diagnosis was 8.75 years. Tumors were more frequently observed among school-age children (42.22\%). Motor deficit was the most common clinical manifestation (97.77\%). Most tumors were intramedullary. Astrocytoma was the most frequent histological subtype. Laminotomy with laminoplasty was the main operative procedure performed in our study. Total resection of the tumors was achieved in $20 \%$ of the cases. Post-surgical complications were observed in $44 \%$ of the cases. Conclusions: Pediatric patients with spinal cord tumors can receive surgical management with an acceptable low surgical morbidity. The clinical phenotype observed in our population has certain similitudes with respect to what it is described in Caucasians.
\end{abstract}

Key words: Spinal cord. Spinal cord tumors. Intramedullary tumors. Extradural tumors.

\section{Características clínicas y manejo quirúrgico de tumores raquimedulares en niños hispanos}

\section{Resumen}

Objetivo: Existe poca literatura acerca de tumores raquimedulares en niños hispanos. Métodos: Realizamos una revisión retrospectiva de 45 niños mexicanos que presentaron tumores raquimedulares entre 1985 y 2015. Resultados: Observamos mayor incidencia de tumores raquimedulares en varones (62.22\%). La edad promedio al momento del diagnóstico fue de 8.75 años. Los tumores fueron observados con mayor frecuencia en niños en edad escolar (42.22\%). El déficit motor fue la manifestación clínica más frecuente $(97.77 \%$ ). La mayoría de los tumores fueron intramedulares. El astrocitoma fue el subtipo

\section{Correspondence:}

*Parménides Guadarrama-Ortiz

Departament of Neurosurgery

Centro Especializado en Neurocirugía y

Neurociencias México

Date of reception: 19-10-2019

Date of acceptance: 20-01-2020

E-mail: investigación.cientifica@ cennm.com

1665-5044/C 2020. Academia Mexicana de Neurología A.C. Published by Permanyer. This is an open access article under the CC BY-NC-ND license (http://creativecommons.org/licenses/by-nc-nd/4.0/).

Available online: $05-08-2020$ Rev Mex Neuroci. 2020;21(4):127-134 www.revmexneurociencia.com
under the CC BY-NC-ND license 
histológico más común. La laminotomía con laminoplastía fue el procedimiento quirúrgico realizado con mayor frecuencia en nuestro estudio. La resección tumoral total se logro en $20 \%$ de los casos. Las complicaciones quirúrgicas ocurrieron en $44 \%$ de los pacientes. Conclusiones: los pacientes pediátricos con tumores raquimedulares pueden recibir tratamiento quirúrgico con una baja morbilidad. El fenotipo clínico observado en nuestra población tiene ciertas similitudes respecto a lo descrito en caucásicos.

Palabras clave: Médula espinal. Tumores raquimedulares. Tumores intramedulares. Tumores extradurales.

\section{Introduction}

Spinal cord tumors are rare in adults and occur at a considerably lower frequency in children. The proportion between spinal cord and intracranial tumors described in the pediatric population varies from 1:4.8 to $1: 20$, depending on the series reviewed ${ }^{1}$. Incidence of spinal cord tumors in high-income countries such as the United States is 1 case $/ 100,000$ children ${ }^{2}$, mainly affecting scholars and adolescents ${ }^{3,4}$. These tumors can arise from the spinal cord or from the adjacent structures, and according to their location, they can be classified as intra- or extradural. Moreover, intradural tumors are divided into intramedullary and extramedullary ${ }^{5}$.

The current literature describes that two-thirds of the total spinal cord neoplasia occurring in children are extradural. These include bone tumors, tumors of the epidural space, and extraspinal tumors that invade such space. On the other hand, $35 \%$ of the spinal cord tumors in pediatric patients are intramedullary, representing $4-6 \%$ of the total central nervous system neoplasia $^{6}$. Astrocytoma, ganglioma, and ependymoma are the histological subtypes most frequently observed in the intramedullary location ${ }^{2}$. Such tumors often localize at cervical and thoracic levels of the spinal cord in almost $50 \%$ of the cases, being less frequently observed at lumbar segments ${ }^{7,8}$. Finally, intradural extramedullary neoplasia is rare and most of them are leptomeningeal metastasis from brain tumors ${ }^{9}$.

Most of what it is currently known about epidemiology and clinical characteristics of spinal cord tumors in children comes from series in Caucasians. However, few studies have described the clinical behavior of these tumors in other populations. In developing countries like Mexico, there are only few reports of spinal cord tumor in children ${ }^{10-12}$, some of which were published before the advent and availability of novel brain imaging tools currently used for the diagnostic and surgical approach of these neoplasia ${ }^{10,11}$. Therefore, it is of major relevance to have updated information about the frequency, clinical behavior, diagnostic tools, surgical strategies, and post-operative clinical outcomes of spinal cord tumors in our children population. Here, we report our experience in the management of spinal cord tumors by reviewing the clinical registries of children that attended and were regularly followed at the Department of Neurosurgery of the Pediatric Hospital of Mexico, a third-level National Reference Center in Mexico City. We believe that our clinical description contributes to the knowledge of spinal cord tumors in Hispanic children and provides valuable data for future studies aimed to compare the clinical behavior of spinal cord tumors among pediatrics with different ethnic backgrounds.

\section{Methods}

We conducted a retrospective review of the clinical and radiological database of the Pediatric Hospital of Mexico "Federico Gomez," looking for clinical cases of children with spinal cord tumors that attended and were regularly followed at our center during the period from 1985 to 2015. Demographic, clinical, and imaging data from participants were retrieved from the database of our hospital. The collected information included relevant neurological manifestations, anatomical location and histological subtype of the tumors, category of imaging tools used for the diagnosis, surgical approaches employed for tumor resection, and post-operative clinical outcomes. Descriptive statistics were used to clinically characterize the study population. Frequencies and proportions were calculated for categorical data. Means, medians, and standard deviations were used for continuous data. Calculations for descriptive statistics were performed using GraphPad Prism v5 (La Jolla, CA, USA). The study was approved by the Ethics Committee of our institution and was conducted with strict adherence to the Official Mexican Law NOM-012-SSA3-2012 that establishes the criteria for the execution of health research projects in humans.

\section{Results}

\section{Participants' characteristics}

A total of 45 children with spinal cord tumors were included in the study. Their mean age at diagnosis was 
Table 1. Clinical characteristics of Hispanic children with spinal cord tumors

\begin{tabular}{|c|c|}
\hline Variable & $n=45$ \\
\hline Age at onset, mean (range) & $8.75(0.5-17)$ \\
\hline $\begin{array}{l}\text { Gender } \\
\text { Male, n (\%) } \\
\text { Female, n (\%) }\end{array}$ & $\begin{array}{l}28(62.22) \\
17(37.77)\end{array}$ \\
\hline Male/female ratio & $1.64: 1$ \\
\hline $\begin{array}{l}\text { Age group } \\
\text { Infants, n (\%) } \\
\text { Pre-scholars, n (\%) } \\
\text { School-age children, n (\%) } \\
\text { Adolescents, n (\%) }\end{array}$ & $\begin{array}{c}4(8.88) \\
9(20) \\
19(42.22) \\
13(28.88)\end{array}$ \\
\hline $\begin{array}{l}\text { Clinical findings before surgical management } \\
\text { Motor deficit, n (\%) } \\
\text { Pain, } \mathrm{n}(\%) \\
\text { Pain referred to the corresponding } \\
\text { dermatomes, } \mathrm{n}(\%) \\
\text { Radicular pain, } \mathrm{n}(\%) \\
\text { Hypoesthesia, } \mathrm{n}(\%) \\
\text { Dysesthesia, } \mathrm{n}(\%) \\
\text { Paresthesia, } \mathrm{n}(\%) \\
\text { Urinary incontinency, n (\%) } \\
\text { Abnormal gait, n (\%) } \\
\text { Fecal incontinence, } \mathrm{n}(\%) \\
\text { Scoliosis, } \mathrm{n}(\%) \\
\text { Kyphoscoliosis, } \mathrm{n}(\%) \\
\text { Falls, } \mathrm{n}(\%) \\
\text { Cervical stiffness, } \mathrm{n}(\%) \\
\text { Muscle contractures, } \mathrm{n}(\%) \\
\text { Hyperreflexia, n (\%) } \\
\text { Clonus, } \mathrm{n}(\%) \\
\text { Atrophy of muscles of the hands, } \mathrm{n}(\%) \\
\text { Hydrocephalus, } \mathrm{n}(\%) \\
\text { Headache, } \mathrm{n}(\%) \\
\text { Seizures, } \mathrm{n}(\%)\end{array}$ & $\begin{array}{l}44(97.77) \\
39(86.66) \\
36(80) \\
3(6.66) \\
38(84.44) \\
25(55.55) \\
13(28.88) \\
29(64.44) \\
16(35.55) \\
10(22.22) \\
18(40) \\
6(13.33) \\
6(13.33) \\
6(13.33) \\
6(13.33) \\
6(13.33) \\
6(13.33) \\
6(13.33) \\
4(8.88) \\
4(8.88) \\
4(8.88)\end{array}$ \\
\hline
\end{tabular}

8.75 years (range 5 months-17 years). The most ancient case occurred 31 years before the conduction of the current study. From these, 28 patients were male $(62.22 \%)$ and 17 female (37.77\%), with a male/female ratio of 1.64:1. The age group with the highest incidence of spinal cord tumors was composed of schoolage children with 19 cases $(42.22 \%)$, followed by adolescents ( 13 cases, $28.88 \%$ ), pre-scholars ( 9 cases, $20 \%$ ), and infants (4 cases, $8.88 \%$ ). All the patients were born in Mexico and their parents referred themselves as belonging to the Mexican Mestizo race. The clinical and demographic characteristics of participants are summarized in Table 1.

\section{Tumors location and histological subtype}

Intramedullary tumors were the most frequent lesions affecting our population, representing the $44.44 \%$ of the cases (20 patients) followed by extradural and
Table 2. Frequency and distribution of spinal cord tumors according to their anatomical location and histological subtype

\begin{tabular}{|l|c|c|c|}
\hline $\begin{array}{l}\text { Localization/ } \\
\text { histological subtype }\end{array}$ & Frequency & $\begin{array}{c}\text { \% of tumors } \\
\text { at specific } \\
\text { localization }\end{array}$ & $\begin{array}{c}\% \text { from } \\
\text { total }\end{array}$ \\
\hline Intramedullary & 20 & -- & 44.44 \\
\hline Astrocytoma & 14 & 70 & 31.11 \\
\hline Ependymomas & 5 & 25 & 11.11 \\
\hline Ganglioma & 1 & 5 & 2.22 \\
\hline Extradural & 18 & -- & 40 \\
\hline PNETs & 6 & 33.33 & 13.33 \\
\hline Metastases & 4 & 22.22 & 8.88 \\
\hline Sarcomas & 3 & 16.66 & 6.66 \\
\hline Neuroblastoma & 1 & 5.55 & 2.22 \\
\hline Lymphomas & 1 & 5.55 & 2.22 \\
\hline Other not specified & 3 & 16.66 & 6.66 \\
\hline Intradural & 7 & -- & 15.55 \\
\hline extramedullary & & & 8.88 \\
\hline Meningiomas & 4 & 57.14 & 2.22 \\
\hline Ependymomas & 1 & 14.28 & 2.22 \\
\hline Schwannomas & 1 & 14.28 & 2.22 \\
\hline Dermoid cysts & 1 & 14.28 & \\
\hline & & & \\
\hline
\end{tabular}

PNETs: primary neuroectodermal tumors.

intradural extramedullary tumors with $18(40 \%)$ and $7(15.55 \%)$ cases, respectively. In addition, six cases of intramedullary lesions were holocordal neoplasia (13.33\%). All cases received histopathological diagnosis. Independently of the tumors' location, astrocytoma was the most frequent histological subtype, followed by primitive neuroectodermal tumors (PNETs), ependymoma, meningioma, and metastases. The frequency and anatomical localization of the different histological subtypes of spinal cord tumors observed in our series are shown in Table 2.

\section{Neurological findings}

The most common clinical findings observed in order of frequency were motor deficit (97.77\%), pain (86.66\%), urinary incontinence (64.44\%), abnormal gait (35.55\%), and fecal incontinence (22.22\%) (Table 1). Furthermore, $53.33 \%$ of patients had alterations of the statics 


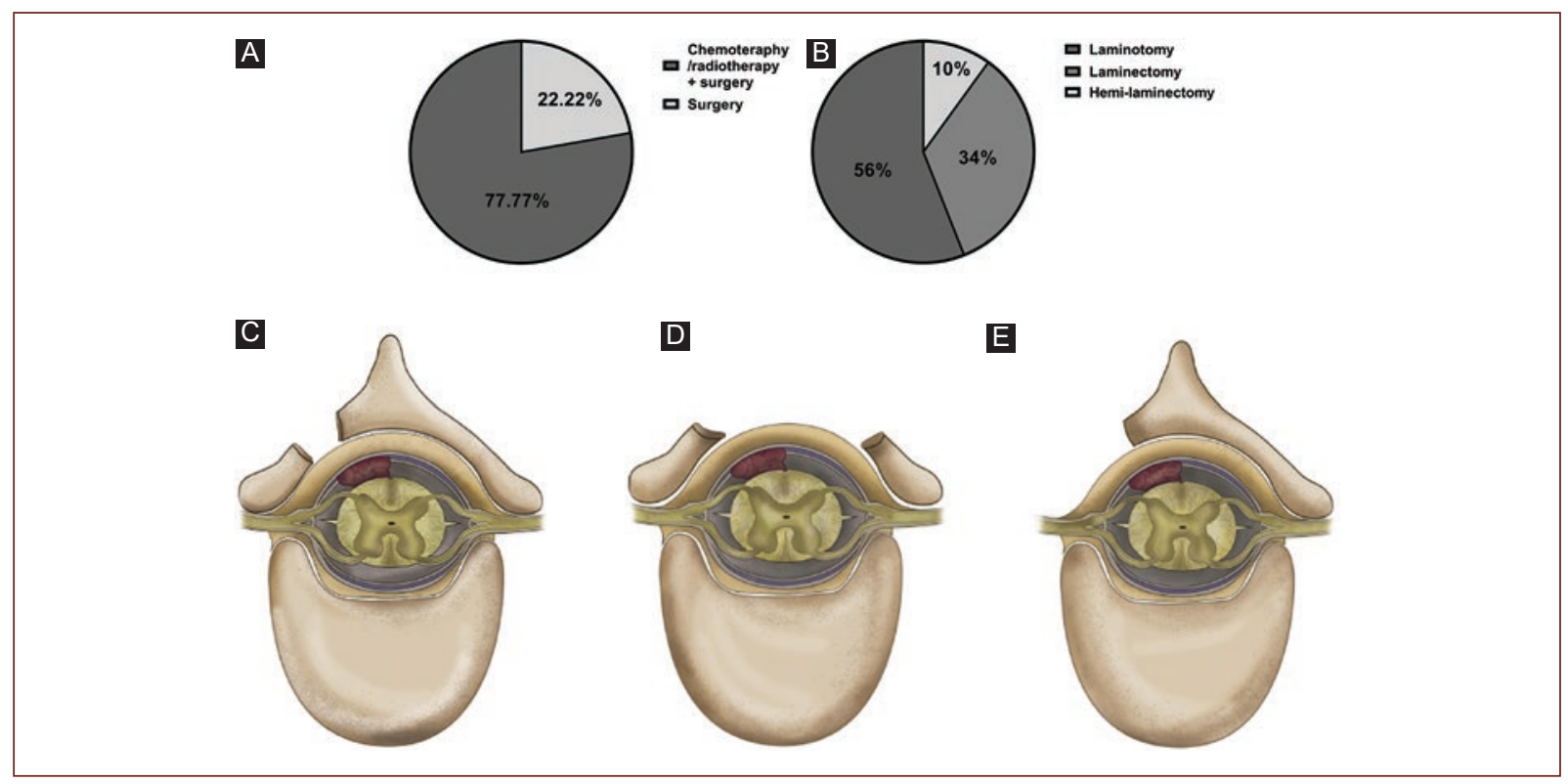

Figure 1. Treatment approaches for pediatric patients with spinal cord tumors. A: Treatment modalities for children with spinal cord tumors. B: Surgical procedures performed for the resection of spinal cord tumors. C: Representative figure of the operative field provided by posterior laminotomy. D: Laminectomy. E: Hemi-laminectomy.

of the spine; 18 cases presented scoliosis (40\%) and 6 had kyphoscoliosis (13.33\%).

Although motor deficit was the main neurological finding, this sign occurred as the first clinical manifestation only in 22 cases (48.88\%). The mean time since the presentation of the motor deficit and surgery was 4.5 months. This deficit was observed in all cases of astrocytoma and intramedullary ependymoma. Other neurological findings observed in our series, especially among patients with cervical-thoracic holocordal tumors included falls, tabetic gait, cervical stiffness, deltoid, supraspinatus, biceps and triceps muscle contractures, as well as hyperreflexia, clonus, and atrophy of intrinsic muscles of the hands.

Regarding pain, this was referred along the dermatomes corresponding to the anatomical location of the tumors in $80 \%$ of patients. This symptom was most common in patients with extradural tumors. Three patients had radicular pain $(6.66 \%)$. Among children affected by cervical tumors, we observed neck pain that was exacerbated with inclination of the head to the contralateral side of the lesion. Sensory deficits manifested as hypoesthesia in 38 cases, dysesthesia in 25 patients, and paresthesia in 13 cases. These sensory alterations always occurred in the dermatomes corresponding to the location of the tumors. Urinary and fecal incontinency occurred in patients with neoplasia of the lumbosacral region or holocordal tumors. Hydrocephalus was detected in 4 cases (8.88\%) and was accompanied by headache and seizures secondary to intracranial hypertension. Neurological features observed in our population are summarized in Table 1.

\section{Diagnostic approach}

From the 45 patients included in the current study, only 13 presented images of brain computerized axial tomography (computed tomography [CT]) scan and magnetic resonance imaging (MRI) at their first medical appointment. Overall, 36 patients underwent to CT scan $(80 \%)$, 38 to MRI ( $84.44 \%), 27$ to electromyography $(60 \%)$, and 31 to evoked potentials $(68.88 \%)$. In 29 cases, urodynamic studies were performed $(64.44 \%)$ including 18 cases with intramedullary tumors. Furthermore, anorectal manometry was performed in 19 patients $(42.22 \%)$, 11 of them with intramedullary lesions.

\section{Surgical management}

Overall, 10 patients were subjected to surgery as their only management strategy, whereas the rest received multidisciplinary oncological management, which included surgery, radiotherapy, and chemotherapy (Fig. 1A). A total of 50 surgical procedures were performed in the 45 cases included in the study (Table 3 and Fig. 1B). Laminotomy was the most 
frequent operative procedure used for the treatment of 28 cases $(56 \%, n=50)$ (Fig. $1 C$ ). From these, 17 were laminotomies followed by laminoplasty as previously described $^{13,14}$. Furthermore, 17 laminectomies (34\%) and 5 hemi-laminectomies (10\%) were performed (Fig. 1D and E). In all cases, a posterior spinal approach was used. For the resection of intramedullary tumors, a classic myelotomy through microsurgical dissection was performed. Ultrasonic cavitation was used only for three cases. The interval from symptoms onset to surgery was lower than 1 month in 3 cases $(6.66 \%)$, 1-6 months in 36 cases (80\%), 7-12 months in 2 cases $(4.44 \%)$, and higher than 12 months in 4 patients $(8.88 \%)$, with an overall mean of $9.5 \pm 8.5$ months (Table 3).

\section{Post-operative clinical outcomes}

A complete tumor resection, defined by negative margins after histopathological analysis, was achieved in 9 cases (20\%; Table 3). From these, five cases were cervical-thoracic astrocytoma, one cervical ependymoma, one cervical PNET, and two thoracic meningioma. All these cases remained without neurological deficits and their mean survival time from onset to the last known follow-up was $10 \pm 4.5$ years. Thirty-six cases had a subtotal tumor resection, from which 19 (52.77\%) had a favorable outcome with no aggravation of the neurological deficit nor recurrence of the tumor after a mean follow up time of $4.5 \pm 2.02$ years. The recurrence status was confirmed on the basis of clinical and imaging findings during the outpatient follow-up period.

The most frequent complications observed after surgery were cerebrospinal fluid fistulas in 9 cases (20\%), post-surgical motor deficit in 6 cases (13.33\%), new-onset urinary incontinence in 3 cases $(6.66 \%)$, hemorrhage in 1 case $(2.22 \%)$, and scoliosis in 1 case $(2.22 \%)$. Finally, 3 dysfunctions (8.88\%) occurred during the period evaluated in the current study and were caused by two anaplastic astrocytoma and one rhabdomyosarcoma.

\section{Discussion}

In the current study, we provide the first clinical description of the full spectrum of tumors affecting the spine and spinal cord in Mexican children ${ }^{11,12}$. Hence, our data may constitute relevant evidence useful for the diagnostic approach and management of spinal cord tumors in non-Caucasian Hispanic pediatric patients from Latin American populations. Based on epidemiological studies conducted at developed countries ${ }^{2}$, the
Table 3. Surgical management and post-operative outcomes in children with spinal cord tumors

\begin{tabular}{|c|c|}
\hline Management modality & $n=45$ \\
\hline Radiotherapy + chemotherapy + surgery, $\mathrm{n}(\%)$ & $35(77.77)$ \\
\hline Only surgical resection, $\mathrm{n}(\%)$ & 10 (22.22) \\
\hline Interval from onset to surgery, mean (SD) & $9.5(8.5)$ \\
\hline$<1$ month, $\mathrm{n}(\%)$ & $3(6.66)$ \\
\hline $1-6$ months, $\mathrm{n}(\%)$ & $36(80)$ \\
\hline 7-12 months, $\mathrm{n}(\%)$ & $2(4.44)$ \\
\hline$>12$ months, $\mathrm{n}(\%)$ & $4(8.88)$ \\
\hline Surgical procedure & $\mathrm{n}=50$ \\
\hline Laminotomy, n (\%) & $28(56)$ \\
\hline Laminotomy + laminoplasty, n (\%) & $17(34)$ \\
\hline Laminectomy, n (\%) & $17(34)$ \\
\hline Hemilaminectomy, n (\%) & $5(10)$ \\
\hline Surgical outcome & $\mathrm{n}=45$ \\
\hline Complete tumor resection, $\mathrm{n}(\%)$ & $9(20)$ \\
\hline Subtotal tumor resection, $\mathrm{n}(\%)$ & $36(80)$ \\
\hline \multicolumn{2}{|l|}{ Post-operative complications } \\
\hline CSF fistula, n (\%) & $9(20)$ \\
\hline Post-surgical motor deficit, n (\%) & $6(13.33)$ \\
\hline New-onset urinary incontinency, $\mathrm{n}(\%)$ & $3(6.66)$ \\
\hline Scoliosis, n (\%) & $1(2.22)$ \\
\hline Hemorrhage, $\mathrm{n}(\%)$ & $1(2.22)$ \\
\hline
\end{tabular}

CSF: cerebrospinal fluid; SD: standard deviation.

incidence of pediatric spinal cord tumors in Mexico is expected to be high, considering that children have constituted a major proportion of the general population in our country during the period of time comprehended in this study. Nonetheless, only 226 cases occurring in our country, including the 45 children described here, have been formally reported in literature during the past 3 decades ${ }^{11,12}$. This suggests a high degree of underdiagnosis and subreport. Despite this, our work and previous local studies show certain similitudes and discrepancies in the clinical phenotype of Mexican Hispanic children with spinal cord tumors with respect to what is described in Caucasian series (Table 4). First, we observed a higher incidence of these tumors in male, and a predominant affection to scholars and adolescents, which have been also reported by other 
Table 4. Clinical characteristics of spinal cord tumors in children from different regions

\begin{tabular}{|l|c|l|c|l|l|c|}
\hline Race/origin & $\begin{array}{c}\text { Age at onset } \\
\text { (years), mean }\end{array}$ & $\begin{array}{l}\text { Predominant } \\
\text { gender }\end{array}$ & Mortality (\%) & Tumor localization & Histological subtype & Reference \\
\hline Hispanic & 8.75 & Male & 8.88 & Intramedullary & Astrocytoma & $\begin{array}{c}\text { Current } \\
\text { study }\end{array}$ \\
\hline Hispanic & -- & Male & -- & $\begin{array}{l}\text { Intradural } \\
\text { extramedullary }\end{array}$ & Dermoid cyst & 11 \\
\hline Hispanic & 5.2 & Male & 21.7 & -- & Primary \\
neuroectodermal & tumors \\
\hline Caucasian & 6.6 & Male & -- & Intramedullary & Dermoid tumors, \\
epidermoid tumors, and \\
teratomas
\end{tabular}

researchers $2,10-12,15,16$. Second, considering the experience of our department in the management of brain neoplasms in children (810 cases in 36 years) ${ }^{17}$, the ratio between spinal cord tumors and intracranial neoplasia derived from the present work (45 cases in 31 years) is 1:15.5 and 1:17.6 if we compare our series with the 511 brain tumors observed during 20 years in the Spanish Hospital of Mexico ${ }^{18}$. These data coincide with the ratio observed in other studies in Caucasians ${ }^{1}$; however, this information may not be accurate due to the possible local degree of underdiagnosis mentioned above.

On the other hand, we observed a higher incidence of intramedullary lesions followed by those of extradural location in our population. In this regard, there is no consensus about the anatomical area most predominantly affected by these tumors since some studies show a higher frequency of extradural lesions ${ }^{16,19,20}$, while others describe a higher incidence of intramedullary tumors ${ }^{15,21-26}$. It is probable that factors specific to each population explain these discrepancies. Our data also confirm the previous descriptions about the most common histological type of spinal cord tumors observed in children ${ }^{2,9}$, as astrocytoma was the most incident tumor in our series regardless of their location. Furthermore, a remarkable finding derived from this work is the high frequency of extradural PNET type neoplasms occurring in our patients, which has been also reported in other Mexican series ${ }^{12}$. These tumors are conformed by undifferentiated cells, with varying degrees of pleomorphism and a slight tendency to acquire neuroectodermal characteristics ${ }^{27}$. Their incidence is extremely low, and some studies show that they represent less than $1 \%$ of all neoplasms that affect the spinal $\operatorname{cord}^{28}$. The average age at which they have been previously diagnosed is 24 years and their exact epidemiology in children remains unknown ${ }^{29}$. Thus, our data suggest that the incidence of spinal cord PNET in the pediatric population may be higher than previously thought.

The identification of spinal cord tumors in children is a major diagnostic challenge due to their rarity and unspecific clinical features. In this regard, our data, as well as previous reports ${ }^{30}$, show that a high proportion of pediatric patients with spinal cord tumors present motor deficits as their initial manifestation. Furthermore, our findings suggest that the presence of pain distributed along with a dermatome, radicular pain, hypoesthesia, paresthesia, dysesthesia, urinary and fecal incontinence, as well as gait disorders in a child otherwise healthy, should suggest the presence of a spinal cord tumor. Regarding surgical management of these lesions, we found that laminotomy by posterior approach is a safe and not deforming procedure, as previously reported ${ }^{13,14}$. Interestingly, we also observed that laminectomy caused kyphosis in only 1 of 17 patients subjected to such procedure at least until the last known follow-up, which represents a lower frequency than reported by other researchers who described that two-thirds of the subjects undergoing laminectomy developed deformity of the spine ${ }^{31}$, especially when laxity of supporting tissues was induced by the adjuvant oncological treatment ${ }^{32}$. Moreover, the occurrence of post-surgical complications in our study was low regardless of the operative approach, and fatal cases were not directly associated with the surgical resection of the tumors. Thus, our data show that pediatric patients with spinal cord tumors can receive surgical management with an acceptable low surgical morbidity. 
Our study possesses all the limitations of a retrospective design in relation to the access and collection of the clinical information. In fact, we could not address the prognostic value of clinical variables and treatment approaches as most of the patients were not further followed after they reach the adulthood. Thus, our survival estimations only represent those patients that remain alive at the last known follow-up. In addition, we did not find objective quantitative evaluations of the post-operative neurological status of the patients within their clinical registries. Such information would have informed us about the effect of the surgical treatment on the neurological functionality. Finally, the fact that the current study was conducted at a single third-level medical center made us unable to perform a population-based comparison, which limited our ability to estimate the local incidence of spinal cord tumors in children and may restrict the representativeness of our data.

\section{Conclusions}

Pediatric patients with spinal cord tumors can receive surgical management with an acceptable low surgical morbidity. The clinical phenotype observed in our population has certain similitudes concerning what it is described in caucasians. This study provides a valuable clinical description of spinal cord tumors that can help in future research in non-caucasian Hispanic children.

\section{Conflicts of interest}

The authors declare that they do not have any conflicts of interest to report.

\section{Funding}

The current study did not receive any financial support.

\section{Acknowledgments}

To the medical and nursing staff of the Pediatric Hospital of Mexico "Federico Gomez."

\section{Ethical responsibilities}

Protection of people and animals. The authors declare that the procedures followed in the current study were performed in agreement to the ethical standards of the responsible human experimentation committee, the World Medical Association, and the Declaration of Helsinki.
Confidentiality of the data. The authors declare that they have followed the protocols of their work center on the publication of patient data.

Right to privacy and informed consent. The authors have obtained the informed consent of the patients and/or subjects referred to in the article. This document is held by the correspondence author.

\section{References}

1. Di Lorenzo N, Giuffre R, Fortuna A. Primary spinal neoplasms in childhood: analysis of 1234 published cases (including 56 personal cases) by pathology, sex, age and site. Differences from the situation in adults. Neurochirurgia (Stuttg). 1982;25:153-64.

2. Constantini S, Epstein FJ. Intraspinal tumors in infants and children. In: Youmans J, editor, Neurological Surgery. $4^{\text {th }}$ ed, Vol. 4. Philadelphia (PA): WB Saundersp; 1996. p. 3123-33.

3. Schellinger KA, Propp JM, Villano JL, McCarthy BJ. Descriptive epidemiology of primary spinal cord tumors. J Neurooncol. 2008;87:173-9.

4. Duong LM, McCarthy BJ, McLendon RE, Dolecek TA, Kruchko C, Douglas LL, et al. Descriptive epidemiology of malignant and nonmalignant primary spinal cord, spinal meninges, and cauda equina tumors, United States, 2004-2007. Cancer. 2012;118:4220-7.

5. Van Goethem JW, van den Hauwe L, Ozsarlak O, De Schepper AM, Parizel PM. Spinal tumors. Eur J Radiol. 2004;50:159-76.

6. DeSousa AL, Kalsbeck JE, Mealey J Jr., Campbell RL, Hockey A. Intraspinal tumors in children. A review of 81 cases. J Neurosurg. 1979;51:437-45.

7. Epstein F, Ragheb J. Intramedullary tumors of the spinal cord. In: Cheek W, editor. Pediatric Neurosurgery: Surgery of the Developing Nervous System. Philadelphia (PA): WB Saunders; 1994. p. 446-57.

8. Brotchi J, Noterman J, Baleriaux D. Surgery of intramedullary spinal cord tumours. Acta Neurochir (Wien). 1992;116:176-8.

9. Rossi A, Gandolfo C, Morana G, Tortori-Donati P. Tumors of the spine in children. Neuroimaging Clin N Am. 2007;17:17-35.

10. Rueda Franco F, Monson de Souza MB, Takenaga Mesquida R. Intraspinal tumors in children. Review of 24 cases. Bol Med Hosp Infant Mex. 1975;32:1073-94.

11. Rueda-Franco F. Tumores intraspinales en niños. Revisión de 130 enfermos. Cir Cir. 1990;57:143-52.

12. González-Sosa E, Anaya-Jara M, Marhx-Bracho A, Rueda-Franco F. Neoplasias espinales extradurales. Experiencia de 15 años en el Instituto Nacional de Pediatría. Acta Pediatr Mex. 2009;30:216-9.

13. Raimondi AJ, Gutierrez FA, Di Rocco C. Laminotomy and total reconstruction of the posterior spinal arch for spinal canal surgery in childhood. J Neurosurg. 1976;45:555-60.

14. Rama B, Markakis E, Kolenda H, Jansen J. Reconstruction instead of resection: laminotomy and laminoplasty. Neurochirurgia (Stuttg). 1990;33 Suppl 1:36-9.

15. Wilson PE, Oleszek JL, Clayton GH. Pediatric spinal cord tumors and masses. J Spinal Cord Med. 2007;30 Suppl 1:S15-20.

16. Spacca B, Giordano F, Donati P, Genitori L. Spinal tumors in children: long-term retrospective evaluation of a series of 134 cases treated in a single unit of pediatric neurosurgery. Spine J. 2015;15:1949-55.

17. Chico-Ponce de León $F$, Castro-Sierra $E$, Perezpeña-Diazconti $M$ Gordillo-Domínguez LF, Santana-Montero BL, Rocha-Rivero LE, et al. Tumores intracraneanos del niño. Bol Med Hosp Inf Mex. 2006;63:367-81.

18. Anaya-Delgadillo $G$, de Juambelz-Cisneros PP, Fernández-Alvarado B, Pazos-Gómez F, Velasco-Torre A, Revuelta-Gutiérrez R. Prevalence of central nervous system tumours and histological identification in the operated patient: 20 years of experience. Cir Cir. 2016;84:447-53.

19. Kanos CC, Muhlbauer MS. Extramedullary, intradural and extradural spinal cord tumors. In: McLone DG, editor. Pediatric Neurosurgery. $4^{\text {th }}$ ed. Philadelphia (PA): WB Saunders Company; 2001. p. 873-84.

20. Wetjen NM, Raffel C. Spinal extradural neoplasms and intradural extramedullary neoplasms. In: Albright AL, Pollack IF, Adelson PD, editor. Principles and Practice of Pediatric Neurosurgery. New York: Thieme; 2008. p. 694-705.

21. Nadkarni TD, Rekate HL. Pediatric intramedullary spinal cord tumors. Critical review of the literature. Childs Nerv Syst. 1999;15:17-28.

22. Albright AL. Pediatric intramedullary spinal cord tumors. Childs Nerv Syst. 1999;15:436-8.

23. Jallo GI, Freed D, Epstein F. Intramedullary spinal cord tumors in children. Childs Nerv Syst. 2003;19:641-9.

24. Townsend N, Handler M, Fleitz J, Foreman N. Intramedullary spinal cord astrocytomas in children. Pediatr Blood Cancer. 2004;43:629-32.

25. Kumar R, Singh V. Intramedullary mass lesion of the spinal cord in children of a developing milieu. Pediatr Neurosurg. 2004;40:16-22.

26. Auguste KI, Gupta N. Pediatric intramedullary spinal cord tumors. Neurosurg Clin N Am. 2006;17:51-61. 
Rev Mex Neuroci. 2020;21(4)

27. Dehner LP. Primitive neuroectodermal tumor and Ewing's sarcoma. Am J Surg Pathol. 1993;17:1-3.

28. Ellis JA, Rothrock RJ, Moise G, McCormick PC $2^{\text {nd }}$, Tanji K, Canoll P et al. Primitive neuroectodermal tumors of the spine: a comprehensive review with illustrative clinical cases. Neurosurg Focus. 2011;30:E1

29. Engelhard HH, Villano JL, Porter KR, Stewart AK, Barua M, Barker FG et al. Clinical presentation, histology, and treatment in 430 patients with primary tumors of the spinal cord, spinal meninges, or cauda equina. J Neurosurg Spine. 2010;13:67-77.

30. Epstein $\mathrm{F}$, Epstein $\mathrm{N}$. Surgical management of holocord intramedullary spinal cord astrocytomas in children. J Neurosurg. 1981;54:829-32.

31. Jallo Gl, Kothbauer KF, Epstein FJ. Intrinsic spinal cord tumor resection. Neurosurgery. 2001;49:1124-8.

32. Constantini S, Miller DC, Allen JC, Rorke LB, Freed D, Epstein FJ. Radical excision of intramedullary spinal cord tumors: surgical morbidity and long-term follow-up evaluation in 164 children and young adults. J Neurosurg. 2000;93:183-93. 